\title{
How to Estimate the Degree of Economic Integration on the Basis of Statistical Methods
}

\author{
Nino Abesadze* \\ Ivane Javakhishvili Tbilisi State University, 0179, Tbilisi, Georgia
}

\begin{abstract}
Purpose of the article: The purpose of the present paper is to identify the methods of statistical evaluation of Georgia's economic integration with the world and calculate the methods of an integration coefficient on the example of Georgia.

Methodology/methods: We conducted the study by using the methods of statistical survey, grouping and analysis: relative-value, mean-value, time series and statistical variation introduction methods. The trend was identified by using simple methods, such as average absolute increase and mean annual growth rate and linear function as an analytical method.

Scientific aim: The scientific aim of the paper is to determine and calculate the coefficient of integration of Georgia with the world economy, as the total aggregated mean arithmetic value of the mean values of the percentages of the integration coefficient values in gross domestic product for each factor calculated in dynamics.

Findings: It was found that the coefficient of integration of Georgia with the world economy was $20,2 \%$ in the considered period. If considering that the percentage value of this coefficient may vary from 0 to 100 . It should be considered that we evaluated the level of integration of the countries by using a three-step scale based on an equalinterval grouping: I) Low (0-33\%); II) Average (33.3-66.6\%); and III) High (66.6-100\%). As the integration coefficient of Georgia in the world economy in $2008-2014$ was $20.2 \%$, this means that Georgia realized only $20.2 \%$ of its foreign economic relations potential in this period.
\end{abstract}

Conclusions: In general, it should be noted that the degree of integration of Georgia in the world economy is quite low and has deteriorated since 2003-2008. As per our calculations, it has decreased by $1.1 \%$. As it turns out, the reduction of the index of integration was mostly the result of the reduced share of investments in GDP.

Keywords: Statistics; Integration; Method; Coefficient; Quality; Prognosis; Dynamics; Jel classification

\section{Introduction}

International economic integration is a new stage of globalization in the modern period. The current level of external economic relations certifies, that the process of enhancing efficiency of the national economy is directly related to the activation of organizationaleconomic factors of deepening the integrative ties.

In this regard it is recommended to evaluate objectively the role and place of Georgian economy in the ongoing processes of globalization and regionalization. It is also important to determine the strategic directions of economic development in accordance with the country interest.

Georgia, due to its geopolitical location, is in the circle of strategic interest of world importance.

The geopolitical location of our country is an important factor in deepening the process of its economic integration in Europe and Asia.

At the present stage of development, the globalization has become the object of the purpose of everyday political, economic and socialcultural life. From the strategic point of view, it is very important for Georgia to enhance the world trade - the economic, financial and other kinds of relations, especially when the foreign interests of Georgia lie in sharing the advanced European values and experiences, and joining the European Union [1].

In order to form the right economic policy of the country it is necessary to conduct the theoretical and practical researches in the area of the integration of Georgia in the world economic space, to study the foreign economic contacts quantitatively, to reveal the main tendencies of the development, to calculate their forecasting indexes, to estimate the results correctly and hence following to work out the appropriate political-economic proposals and preventive measures [2].

It is a fact that the success of the development of the national economies immediately depends on the degree of the countries' participation in the processes of integration.

The integration process develops by multilateral direction. On base of the information of official statistics office we specified indicators of relations with the outside world of Georgia: relations with the rest of the world in respect of primary incomes, current transfers, foreign trade, investments and foreign debt, share of the revenue from the international tourism in GDP They determine economic development of the country. Indicators share, were used by us for calculation of coefficient of integration and for the evaluation of quality of integration.

We were determining the modern level and scales of the integration processes, one of the major factors in determining the foreign policy strategy is the correct assessment by using the statistical methods of

*Corresponding author: Abesadze N, Ivane Javakhishvili Tbilisi State University 0179, Tbilisi, Georgia, Tel: +995 3222251 07; E-mail: ninka_abesadze@yahoo.com

Received May 04, 2017; Accepted June 05, 2017; Published June 30, 2017

Citation: Abesadze N (2017) How to Estimate the Degree of Economic Integration on the Basis of Statistical Methods. Intel Prop Rights. 5: 190. doi: 10.4172/23754516.1000190

Copyright: ( 2017 Abesadze N. This is an open-access article distributed under the terms of the Creative Commons Attribution License, which permits unrestricted use, distribution, and reproduction in any medium, provided the original author and source are credited. 
Citation: Abesadze N (2017) How to Estimate the Degree of Economic Integration on the Basis of Statistical Methods. Intel Prop Rights. 5: 190. doi: 10.4172/2375-4516.1000190

Page 2 of 4

the integration processes. For this purpose, the statistical information depicting the course of events and their relevant analysis is needed. It is at this point where the importance of reliability of the statistical information is particular clear. In addition, the right expectation of the change of the integration processes allows identifying the necessary resources and adequate regulations. Using such an approach to integration has led to a particular interest in its scientific study by using the statistical methods. The scales of the integration processes fixed in the country and striving to the world values, changes in the socialeconomic life, rates of economic development and revealed trends required a novel comprehension of the theoretical issues of statistics depicting the integration processes and introduction of the practical methodological mechanism, which is scientifically approved in the world statistics based on the international experience.

Following the above-mentioned, the purpose of the paper is to identify of the statistical evaluation of the degree of integration of Georgia with the world and calculation of the integration coefficient on the example of Georgia.

The subject of the paper study is the quantitative indicators of the economic integration of Georgia with the world and the object of the study is the major trends in the economic integration with the world in 2008-2015.

The theoretical base of the study was the works by Georgian and foreign scientists and economists concerning this topic. The following authors are worth mentioning: Papava V, Silagadze A, Ghaghanidze G, Korganashvili L, Kandashvili T, Khmaladze M, Paresashvili N, Putkaradze R, Gelitashvili N, Abesadze O and others. Their works describe the economic aspects of the Euro-integration processes, expectations of the Euro-integration, challenges and problems of Georgia, etc.

The calculation and evaluation of the integration coefficients are of a great practical value, as they can be used as the basis for rating the countries. The indicator can also be calculated according to the groups of the countries. The indicator calculated for each country shows the integration level of eth given country in the world economy what will allow analyzing the genera integration level and structural analysis.

\section{Methodology/Methods}

We conducted the study by using the methods of statistical survey, grouping and analysis: relative-value, mean-value, time series and statistical variation introduction methods. The trend was identified by using simple methods (average absolute increase and mean annual growth rate) and linear function as an analytical method.

During calculation of coefficient of Integration we used types of statistical data: absolute, relative and average values.

\section{Scientific aim}

The scientific aim of the paper is to determine and calculate the coefficient of integration of Georgia with the world economy, as the total aggregated mean arithmetic value of the mean values of the percentages of the integration coefficient values in gross domestic product for each factor calculated in dynamics.

\section{Calculation of the integration coefficient}

The methods to calculate the degree of integration of Georgia in the world economy are based on the identification of the principal factors having an impact on the country's integration with the world economic processes. Such factors are: relations with the rest of the world in respect of primary incomes, current transfers, foreign trade, investments and foreign debt. As tourism in Georgia is a priority in the development of the country and its share in GDP tends to increase regularly, by considering the recently identified trends, the revenue gained from the international tourism in GDP was added to the system of indicators of the integration of the country with the world economy.

Naturally, at the beginning, we calculated the shares of the indicators for each factor in GDP in dynamics (Table 1).

Then, we calculated mean arithmetic values of the indicators in columns and rows. The results are given in the last column and row. Then, we calculated the mean arithmetic values from the mean percentage values of the gained indicators of foreign economic relations and gained the coefficient at the crossing of the last column and row (Table 2).

\begin{tabular}{|c|c|c|c|c|c|c|c|c|}
\hline $\begin{array}{l}\text { Relations with the world: (percentage } \\
\text { share in GDP) }\end{array}$ & 2008 & 2009 & 2010 & 2011 & 2012 & 2013 & 2014 & 2015 \\
\hline Primary incomes & 9.3 & 8.9 & 10.3 & 13.4 & 14.5 & 13.3 & 12.9 & 14.7 \\
\hline Current transfers & 9.6 & 10.3 & 10.9 & 10.9 & 10.3 & 10.5 & 10.3 & 12.3 \\
\hline Foreign trade & 60.9 & 52.3 & 59.6 & 64.1 & 65.8 & 67.7 & 69.3 & 71 \\
\hline Investments & 12.2 & 6.1 & 7.0 & 7.7 & 5.8 & 5.8 & 10.7 & 11.2 \\
\hline Foreign debt & 19.4 & 25.2 & 28.0 & 24.7 & 25.3 & 26.4 & 26.6 & 32.4 \\
\hline Revenue from the international tourism & 0.6 & 0.9 & 3.2 & 3.9 & 5.3 & 6.4 & 6 & 6.7 \\
\hline
\end{tabular}

Table 1: Share of indicators in GDP. Source: Author's own compilation based on the materials of the National Statistics Office of Georgia.

\begin{tabular}{|c|c|c|c|c|c|c|c|c|c|}
\hline Relations with the world: (percentage share in GDP) & 2008 & 2009 & 2010 & 2011 & 2012 & 2013 & 2014 & 2015 & 2015 \\
\hline Primary incomes & 9.3 & 8.9 & 10.3 & 13.4 & 14.5 & 13.3 & 12.9 & 14.7 & 12.2 \\
\hline Current transfers & 9.6 & 10.3 & 10.9 & 10.9 & 10.3 & 10.5 & 10.3 & 12.3 & 10.6 \\
\hline Foreign trade & 60.9 & 52.3 & 59.6 & 64.1 & 65.8 & 67.7 & 69.3 & 71 & 63.8 \\
\hline Investments & 12.2 & 6.1 & 7.0 & 7.7 & 5.8 & 5.8 & 10.7 & 11.2 & 8.3 \\
\hline Foreign debt & 19.4 & 25.2 & 28.0 & 24.7 & 25.3 & 26.4 & 26.6 & 32.4 & 26 \\
\hline Revenue from the international tourism & 0.6 & 0.9 & 3.2 & 3.9 & 5.3 & 6.4 & 6 & 6.7 & 4.1 \\
\hline $\begin{array}{l}\text { Mean value of the sum of indicators of foreign economic } \\
\text { relations, } \%\end{array}$ & 18.7 & 16.3 & 19.8 & 20.8 & 21.2 & 21.7 & 22.6 & 24.7 & $20.8 / 20.8$ \\
\hline
\end{tabular}

Table 2: Aggregate indicators of the integration coefficient. Source: Author's own compilation based on the materials of the National Statistics Office of Georgia. 
This is in fact the aggregated sum of the foreign economic relations and the coefficient of integration with the world economy, and is $20.8 \%$.

As the coefficient describes the degree of integration of Georgia with the world economy, the indicated value means that Georgia could realize only $20.8 \%$ of its potential of foreign economic relations. In 2014, the integration rate was equal to $20.2 \%$. This means that in 2008-2014, Georgia could realize only $20 \%$ of its foreign economic potential [3]. So in 2015 , compared with 2014 , although slightly, but was increased the scale use of the potential of the Foreign Relations.

It is clear that the percentage value of this coefficient may vary between from 0 to 100 . Naturally, its value close to 0 means that the country has no foreign relations at all, while its value close to 100 means that the country develop only at the expense of foreign relations [4].

For the comparative analysis of the dynamic picture of Georgia's integration with the world economy, we calculated the integration coefficient based on the above-referred indicators by considering the data of 2003-2008 as well. The gained value of the integration coefficient was $21.1 \%$ meaning that Georgia could realize $21.1 \%$ of its potential for foreign economic relations in this period. When evaluating the integration coefficient, we used the principle of mechanical distribution and assessed the level of integration of the countries by using a threestep scale based on the equal-interval grouping: I) Low (0-33\%); II) Average (33.3-66.6\%), and III) High (66.6-100\%). Based on this classification, in 2008-2014, Georgia was among the countries with low level of integration.

It is a fact that a major part of the population of Georgia lives on the money transfers from foreign countries, including the CIS or EU countries. Surely, the value of such funds will have a certain effect on the degree of integration of Georgia with the world economy. As per the declared data, an average foreign package per household is $36 \mathrm{Gel}$ (i.e. $10 \mathrm{Gel}$ per capita). This is $42.9 \%$ more the same indicator of 2010 and $80 \%$ more than that in 2008 . Only in 2014 , the volume of money transfers was 1440754.3 USD, including $30.3 \%$, or 436062,7 USD from the $\mathrm{EU}$ and $53.5 \%$ or 770781.8 USD from the CIS countries. It is true that the size of transfers was $2,5 \%$ less than that in the previous year, but it has shown a trend of absolute growth in recent years. Out of the EU countries, the greatest funds, as expected, arrive from Greece, Italy, Spain, Germany and UK; as for the CIS countries, Russia ranks the first in the respect, followed by Azerbaijan and Kazakhstan [5].

As we have seen, the degree of integration of Georgia with the world economy is quite low showing a fall of $1.1 \%$ since $2003-2008$ as our calculations evidence. Despite the favorable current investment environment in Georgia both, for local and foreign investors (the investment environment in Georgia is liberal, the country offers equal opportunities to local and foreign investors, there is free market economic policy, there are only 6 types of taxes and with reduced tariffs, the country has a favorable geographical location and its investment potential increases making Georgia more attractive for foreign investors), it turned out that the investments were mostly reduced at the expense of the reduced share of investments calculated in GDP. This is what the statistics evidences [6].

\section{Foreign direct investments in Georgia}

The size of foreign direct investments in Georgia was 1758.4 million USD in 2014 which is $87 \%$ more the fixed value of foreign direct investments in previous year. In 2015, the size of investments was 1564.5 million USD which is $11 \%$ less than the previous year's corresponding figure. The highest value of foreign direct investments of 2015 million USD was fixed in 2007 which is $69.3 \%$ more than the same value in the previous year. High rates of investments were maintained to August of 2008. After a drastic fall, high rates of the foreign direct investment growth are seen from 2010. This value in 2011 increased by $37 \%$ since the previous year and made 1117.2 million USD; In 2012, the size of investments in Georgia decreased by 18\% (912 million USD); the year of 2013 was very important for the economy of Georgia, as the economy and business in the country were freed from the political press, a liberal environment to develop production was established in the country and entrepreneurs were allowed to identify the developmental priorities for their businesses on their own, surely with their property rights protected. In 2014, the size of investments was 1758.4 USD which was $37 \%$ more than the same indicator in 2013 (Figure 1) [7-10].

As per the data of 2014, the size of reinvestment was $21 \%$ of the total foreign direct investments. The table below shows the share of reinvested funds in the total FDIs in 2010-2014 (Table 3).

As it can be seen, the lowest value of the specific weight of reinvested

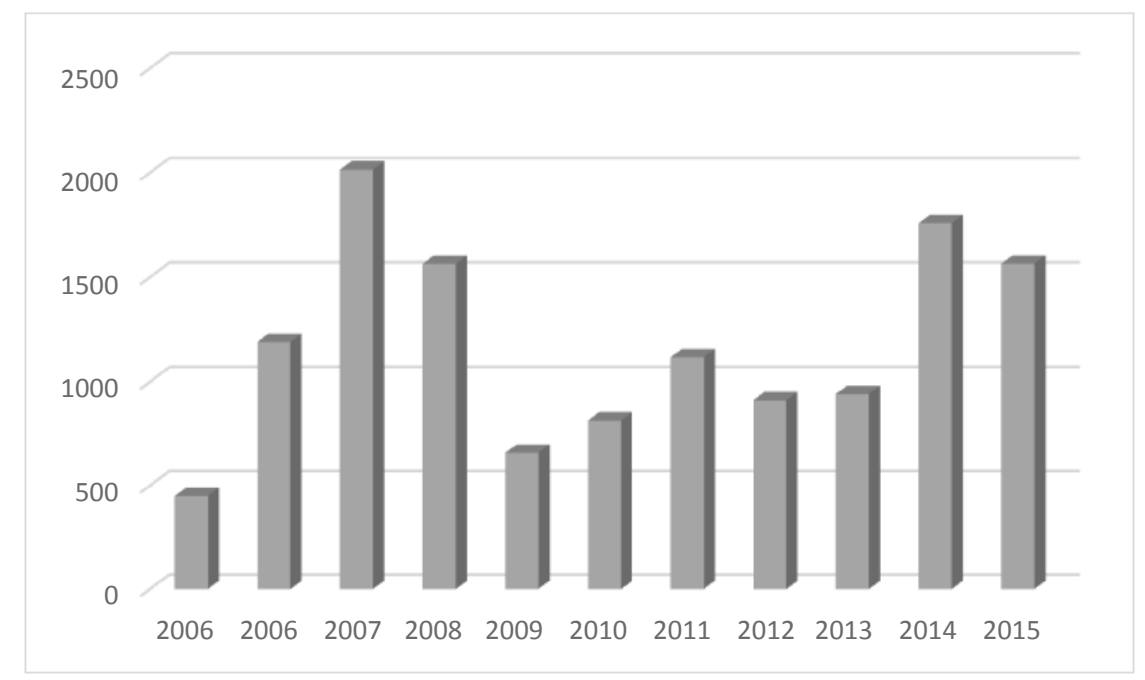

Figure 1: FDI in Georgia in 2010-2015 (Million US Dollars). Source: National Statistics Office of Georgia. 
Citation: Abesadze N (2017) How to Estimate the Degree of Economic Integration on the Basis of Statistical Methods. Intel Prop Rights. 5: 190. doi: 10.4172/2375-4516.1000190

\begin{tabular}{|l|c|c|c|c|c|c|}
\hline Year & $\mathbf{2 0 1 0}$ & $\mathbf{2 0 1 1}$ & $\mathbf{2 0 1 2}$ & $\mathbf{2 0 1 3}$ & $\mathbf{2 0 1 4}$ & $\mathbf{2 0 1 5}$ \\
\hline $\begin{array}{l}\text { Index } \\
\text { in total FDI, \% }\end{array}$ & 28 & 30 & 13 & 28 & 19 & 9 \\
\hline
\end{tabular}

Table 3: Reinvesting of foreign direct investments in Georgia in 2010-2014. Source: National Statistics Office of Georgia.

funds received as the revenue from the primary investment in the foreign direct investments was fixed in 2012 what evidences that only $13 \%$ of the revenue from the investment was reinvested following the unfavorable investment and business environment for the investors. In 2013, this value nearly doubled what is a positive trend, but in 2014 this indicator was decreased by $22 \%$ and amounted 19\%. In 2015 in comparison with previous year this one have decreased by $68 \%$ and amounted to $9 \%$ [11-14].

Such a tendency led to the reduction of the mean investment value thus reducing the average share of investments in GDP in dynamics.

On the background of the economic picture of Georgia, we can conclude that this coefficient gives a real picture of the degree of integration of Georgia with the world economy, which unfortunately is quite low. Therefore, the government of Georgia has been facing a significant challenge: to develop an optimal plan for the country's economic development, promote the revival of domestic production and strengthening the process of integration of Georgia in the world economic space [15].

\section{Discussion}

Different scientists expressed different views of the integration coefficient. Some scientists, e.g. Prof. M. Khmaladze, do not include the revenue from the international tourism in the integration coefficient [16]. Consequently, the share of tourism in GDP was not taken into account when calculating the integration coefficient. However, we think that the share of tourism in GDP should be taken into account for such a calculation, as tourism is a priority for the development of the economy of Georgia and the number of international inbound tourist's increases regularly. Therefore, the indicator modified by us describes the degree of integration more thoroughly [17]. In addition, the size of money transfers, what is so important for Georgia, must be taken into account.

Of course, other relative indicators, too can be used in calculations what will obviously improve the methodology to calculate the coefficient of integration [18].

\section{Conclusion}

So, we can briefly formulate the integration coefficient of a country with the world economy as a total aggregated mean arithmetic of the mean values of the percentages of the indicators in GDP for each factor of the calculation.

Generally, it should be noted that the degree of integration of Georgia with the world economy is quite low $(20.8 \%)$ what has been deteriorated since 2003-2008 as our calculations demonstrate (it decreased by $1.1 \%)$. As mentioned above, the present investment policy in Georgia is favorable both, for local and foreign investors. Besides, despite the liberal investment environment in the country, as there are equal opportunities for local and foreign investors and free market economic policy, the investment potential of Georgia is improved making the country more attractive for foreign investors, as it turned out, the reduction of the index of integration is mostly the result of the decreased share of the indicators in GDP calculated based the investments.
By considering the general economic picture of Georgia, we can conclude that this coefficient describes the degree of integration of Georgia with the world economy in real terms. In our opinion, provided the integration coefficients of the countries are calculated on a regular basis, such a calculation may well become the basis for rating the countries.

\section{References}

1. Abesadze $O$ (2015) The Influence of European Neighbouring Policy Upon the Economic Development of Georgia. Procedia-Social and Behavioral Sciences 213: 557-561.

2. Abesadze N (2014) The Main Trends of Integration of Georgia into the World Economic System. Procedia- Social and Behavioral Sciences 156: 166-169.

3. Gelashvili S, Abesadze N, Abesadze O (2015) Expected Trends in Trade Relations Between Georgia and the European Union. Folia Pomeranae Universitatis Technologiae Stetinensis. Oeconomica 81: 4 37-46.

4. Abesadze N (2013) The methodological issues of the improvement of gende statistics of employment. Economics and Management.18(1): 154-158.

5. Abesadze N (2015) Statistical analysis of the Economic Integration of Georgia with the European Union and Prospects for Development. Economics and Management 19(4): 333-337.

6. Abesadze N (2015) "The Statistic Indexes of Penetrating the Products Manufactured in Georgia into Euro pean Market". Procedia-Social and Behavioral Sciences (213: 569-573).

7. Gelitashvili N (2011) The model of social defense compatible with EU in Georgia. Dissertation 25-55.

8. Kandashvili and Temur (2002) Georgian export and its stimulation, dissertation, Tbilisi: Publishing TSU, 50-85.

9. Putkaradze R (2010) Trade and economic relations between Georgia and the EU: problems and prospects. UDC 22(4): 201-258.

10. Papava V (2015) Economics of Georgia. Tbilisi. Inteleqti Publications 2052022.

11. Paresashvili N (2013) Policy Implementation of the Eastern Partnership in Georgia. Journal Public Policy and Administration 12: 40-46.

12. Silagadze A (2013) Priorities for the Economy of Postcommunist Georgia in the Context of the World Financial Crisis J Problems of Economic Transition 5: 8-63.

13. The issues of Euro-integration (2013) Visegrad countries and South Caucasus 12-24.

14. Approaching Europe - the economic and social policy in Georgia, Armenia and Azerbaijan (2010) 15-32, 94-102.

15. Korganashvili L (2014) Prospects of development of foreign economic relations of Georgia in the circumstances of globalization and regional integration. IV International Congress Caucasus and Central Asia in Globalization Process. Baku 264-273.

16. Ghaghanidze G (2011) Export potential growth alternatives: diversification and concentration. The Journal Economics and Business 3: 171-184.

17. Is the EU regional policy the source of inspiration for the countries beyond the EU (2009) Bulletin 4-15.

18. Chmaladze M (2012) Statistics for economics and management. Tbilisi: Meridiani Publications 218-233 Official web page of National Statistics Office of Georgia. www.geostat.ge. 